\title{
UNIVERSITYOF
}

FORWARD

THINKING

WESTMINSTER用

WestminsterResearch

http://www.westminster.ac.uk/westminsterresearch

The filmic fugue of Ken Russell's Pop Goes the Easel

Wyver, J.

This is a copy of the final published version of an article published in Journal of British Cinema and Television, 12 (4), pp. 438-451.

(c) Edinburgh University Press

The published version by Edinburgh University Press is available online at:

https://dx.doi.org/10.3366/jbctv.2015.0279

The WestminsterResearch online digital archive at the University of Westminster aims to make the research output of the University available to a wider audience. Copyright and Moral Rights remain with the authors and/or copyright owners.

Whilst further distribution of specific materials from within this archive is forbidden, you may freely distribute the URL of WestminsterResearch: ((http://westminsterresearch.wmin.ac.uk/).

In case of abuse or copyright appearing without permission e-mail repository@westminster.ac.uk 


\section{The filmic fugue of Ken Russell's Pop Goes the Easel}

John Wyver, University of Westminster

[Revised version, 24 May 2015]

First broadcast as an episode of BBC Television's Monitor on 25 March 1962, Ken Russell's documentary film Pop Goes the Easel opens with an explosion of freewheeling exuberance. Flirting and having fun, three men and a woman, each perhaps in their early twenties, wander through a fairground at night. As viewers we can identify the subjects only because, for the first television broadcast at least, we were introduced to them in an introductory prologue with strand editor Huw Wheldon. Shot in high-contrast monochrome, the hand-held images were filmed by Ken Higgins, and Allan Tyrer edited them immaculately to James Darren's hit single 'Goodbye Cruel World [l'm Off to Join the Circus]'. The informal framing and cutting suggest cinema verité documentary, but the use of non-diegetic pop music was entirely alien to observational filmmakers at the time. The cinematic language similarly references the early films of the French nouvelle vague, including Francois Truffaut's Les Quatres cents coups (The 400 Blows, 1959) and Jean-Luc Godard's À bout du soufflé (Breathless, 1960). Yet there are also eccentric interpolations: at a stall we see one of the men shoot a toy rifle and the next image is a stock shot of a cowboy returning his fire. Compared with the dominant forms of factual television of the time, the scene is especially notable, as is the documentary as a whole, for the absence of voice-over narration.

In retrospect, Pop Goes the Easel, and perhaps especially this opening, has acquired a resonant poignancy. One of the four young people is the artist and actress Pauline Boty, who was 24 in these early months of 1962, but who after a short, successful career would die of cancer in the summer of 1966 (Tate, 2003). The other characters in the quartet are also visual artists. Peter Phillips was still a student at the Royal College of Art (RCA) while Derek Boshier, like Boty, had just completed his studies, and the work of the slightly older RCA alumnus Peter Blake was beginning to be recognised by 
galleries and collectors. Later in the film observational sequences recorded with synchronous sound (in contrast to the opening) reveal the ideas of these artists about their world and about their paintings and collages. As a consequence, Pop Goes the Easel is a rich and revealing document of early Pop Art in London, as is rigorously explored by art historian Lisa Tickner (2012). ${ }^{1}$

Problems with music rights compounded BBC Television's institutional amnesia and meant that Pop Goes the Ease/ was largely inaccessible for many years. ${ }^{2}$ As a consequence it remains less well known than Ken Russell's Elgar, also made for Monitor and first broadcast eight months later on 11 November 1962. This article is intended as a contribution to the emerging recognition of the earlier film, situating it within the context of television's engagement with the visual arts in the medium's first 25 years. I argue that part of its significance within the tradition of the visual arts on television is its resistance to the determinations of an explanatory voice. Also, that its achievement combines and develops approaches of photojournalism, documentary and art cinema from the mid- and late 1950s. Yet Pop Goes the Easel is also especially note-worthy for its finely-balanced tensions between discourses traditionally understood as oppositional: the stasis of artworks versus the linear narrative of film; the indexical qualities of documentary versus the inventions of fiction; the mass-produced elements and images of popular culture versus the individual authorship and authority of high art; the abstracted rationality of critical discourse versus explosions of embodied sensuality; and the determinations and closure of a singular

\footnotetext{
${ }^{1}$ Lisa Tickner's exceptional study of Pop Goes the Easel and its cultural context, which she shared personally with me, remains unpublished at the time of writing; I am particularly grateful to her for access to her research and ideas, and especially for the Roland Barthes reference about Pop Art.

2 Pop Goes the Easel was repeated on 29 July 1963, and on 11 August 1977 it represented the year 1962 in BBC Two's Festival 77 anniversary series of repeats. The film was not broadcast again until a showing on BBC Two as part of The Pop Show on 14 September 1991 and then a BBC Four showing on 28 September 2008. For the later broadcasts certain music tracks used in the original (which proved to be unclearable) were replaced. Off-air recordings of the BBC Four transmission can now be accessed on YouTube and elsewhere, although unlike Elgar and Song of Summer (1970), the film has not to date been released on DVD.
} 
meaning versus polysemous openness. The assumed dichotomies of certain of these pairings was beginning to be questioned within British culture at the time, and while Pop Goes the Easel contributes to such debates it does so not by attempting to dissolve the boundaries that separate the concerns but rather by revealing and giving expression to the tensions between them. Following a characterisation by Roland Barthes of Pop Art in general, as discussed below, we might understand the play of the forces that structures Pop Goes the Easel as a filmic fugue of counter-pointed concerns.

\section{Artists on the small screen}

Although very few early programmes about the arts survive, by 1962 British television had established a strong tradition of the presentation of and engagement with the visual arts. In part this had been inherited from radio, as was the case with so much about the inherently intermedial forms of early television. From the first days of broadcasting, the BBC's first DirectorGeneral John Reith had directed BBC producers 'to carry into the greatest possible number of homes everything that is best in every department of human knowledge, endeavour and achievement' (1924: 34). The arts, including the visual arts and architecture, were central to this mission, and following its debut on 2 November 1936 BBC Television extended the programme of talks and discussions that radio had offered on a regular basis. On just the third day of the regular high definition service, the artist John Piper introduced artworks in a studio at Alexandra Palace to the tiny middle-class metropolitan audience that lived within a radius of perhaps twenty miles of the single transmitter (Radio Times 1936: 89). Piper regularly presented paintings and sculptures from commercial gallery exhibitions in London, and his programmes were soon complemented by comparable illustrated lectures by the painter Sir Gerald Kelly, later to be President of the Royal Academy, and Kenneth Clark. Then Director of the National Gallery, Clark used reproductions of the nation's Florentine paintings in a broadcast on 17 December 1937 (Wyver 2014: 125). Artists other than Piper also appeared before the cameras, including Paul Nash, who gave 'an interpretation of surrealist art by means of exhibits from England and abroad' 
(Radio Times 1938: 17), and Wyndham Lewis, who participated in the 1939 televised discussion Traditional versus Modern Art (The Listener 1939). The first live outside broadcast concerned with the visual arts came from the Royal Academy of Arts on non-members varnishing day, 24 April 1939, in a programme presented by portraitist Edward Halliday (Radio Times 1939: 16).

Following the post-war return of the television service in June 1946, regular live broadcasts about the arts continued from Alexandra Palace. Produced by the Talks Department of the Television service, these programmes invariably accorded primacy to the word, stressing the centrality of verbal interpretation of the visual. Roland Barthes identified the 'anchorage' of a printed image by a written text, ensuring that the text directs the reader through the signifieds of the image, causing him to avoid some and receive others... it remote controls him towards a meaning chosen in advance.' (Barthes 1977: 40) On television, the spoken word operates in a way comparable to that of the text as analysed by Barthes. So for the edition of the series The Eye of the Artist broadcast on 7 October 1947, Radio Times promised that the critic R. H. Wilenski would speak with three artists, including John Skeaping, as they worked, and that Wilenski would 'discuss [...] the ideas behind their pictures' (Radio Times 1947: 35). Of Life Class, another programme in the series, Radio Times details that Henry Carr 'explains and illustrates traditional methods of instruction' for drawing from life (emphasis added) (Radio Times 1948: 26). The reliance on verbal explanation inherited from radio continued throughout the 1940s and 1950s to dominate the visual arts in the television studio. Complementing these broadcasts, however, were presentations of documentaries about the visual arts purchased from abroad, including Francois Campaux's Matisse (1946), first shown on 28 November 1947, and Luciano Emmer and Enrico Gras's film Lost Paradise (1950) about the work of Hieronymus Bosch, broadcast on 16 November 1950. Both of these films construct their narrative and meanings primarily through images and montage, as do other European films about Van Gogh and Michelangelo that were screened in these post- 
war years. But the BBC screenings required spoken introductions by an onscreen commentator, who for Matisse was the writer Geoffrey Grigson and for Emmer and Gras's film the controversial critic and curator Le Roux Smith Le Roux, then newly appointed as Deputy Keeper at The Tate Gallery.

Only in May 1951 did the television service broadcast a film documentary about the visual arts that had been produced by the BBC. John Read's Henry Moore observed the sculptor at work on his Stringed Figure, 1951, commissioned for a central position at the South Bank site of the Festival of Britain (Wyver 2007: 17-20). ${ }^{3}$ With a commentary written by Read and spoken by the actor Bernard Miles, the documentary located the artist in a tradition of Romantic modernism, recuperating Moore's politically and aesthetically radical work from the 1930s within a context of post-war liberal humanism. The focus of Moore's art on the human figure was stressed while at the same time his work was seen as extending a 'timeless' English tradition of pastoralism. John Read's film revels in the camera's liberation from the television studio, and Henry Moore's sculptures are shown in his studios at Perry Green and in the surrounding landscape. Monumental bronzes are shown silhouetted against the sky and set in motion, with sculptures and the camera at separate moments set on a turntable. Comparatively lengthy shots simply expose the sculptures solely to an accompaniment of William Alwyn's expressive score. Yet at the same time the meanings of the sculptures are established and held in place by the narrating voice, as is underlined by this fragment of Read's script: 'Sculpture of this kind is a challenge to our accepted ideas and we must understand the sculptor's approach to his work before we can appreciate the work itself.' The narrating voice of Henry Moore also reflects the dominant tone for the television presentation of the visual arts throughout the 1950s, as can also be recognised in John Read's second film with Moore made in 1958, as well as his other documentary studies like John Piper and Graham Sutherland

\footnotetext{
${ }^{3}$ The film is available online from BBC Archive:

http://www.bbc.co.uk/archive/henrymoore/8801.shtml; accessed 2 February 2015.
} 
(both BBC, 1953) and Stanley Spencer (BBC, 1956). Modern British art is constructed by Read's camera as rural rather than urban, individual rather than mass-produced, organic and not technological, inherently English, and only modestly modernist, with a critique rather than an embrace of the contemporary material world. This interpretative framework, which carries across to Monitor from 1958 onwards, assumes that what John Read called 'the imaginative element in the human personality' ('P. L.' 1983: 27) was under threat from an increasingly materialistic and technological society. Part of the televisual originality of Pop Goes the Easel is its rejection of this cluster of ideas, evidenced by its enthralled and uncritical gaze at the city, at technology and at the operations of advertising and consumption.

Commercial television started in Britain in 1955, and ITV soon found a champion of the arts in Kenneth Clark, who was Chairman of the Arts Council of Great Britain (1953-1960) and who had been the founding Chairman of the Independent Television Authority (1954-1957). From February 1958 he presented a regular series of arts programmes for the ITV contractor ATV, initially under the title Is Art Necessary? and later as the lecture series Five Revolutionary Painters (1959) and Landscape into Art (1961) (Stephens and Stonard 2014: 141-143). With sparing use of nonstudio sequences, Clark's first programmes were discussions of abstract topics such as 'Should Every Picture Tell a Story?' (broadcast 14 April 1958), for which he was joined by the painter and critic John Berger, and 'What is Good Taste?' (1 December 1958). Clark recognised, however, that the programmes were failing to engage an audience. " "What we want to do is to tell stories," ' Clark's producer Michael Redington recalled him as saying. ' "That's what people like, isn't it? A narrative." ' (Redington 1993) Across these programmes, Clark's singular voice achieves an unchallenged dominance, defining and interpreting the artworks shown on screen. Yet here, as in his later series Civilisation (BBC, 1969), he is concerned to offer access to the widest possible audience to the great works of the past, and to see his stance as simplistically paternalist is a misjudgement. Clark had few doubts about his evaluations of the visual arts up to the end of the 
nineteenth century, and he wanted to share his knowledge and understanding with his television viewers. At the same time there is nothing in these programmes that engages with and embraces the art of the postwar world, let alone the emerging forms of popular culture that would be so central to Pop Goes the Easel.

\section{Ken Russell at Monitor}

The BBC started its arts magazine show Monitor in February 1958, and Ken Russell began to make films for the strand the following year. As might have been expected the focus of the series was on the high arts, with the first programme ranging across a study of musique concrete, interviews with novelist Kingsley Amis and playwright Tennessee Williams, and a consideration of the sculpture of Jacob Epstein, plus Joseph Cooper at the piano. Many of the items in the series gave primacy to the word in studio interviews, discussions and lectures From the start, however, Monitor was concerned to present both short films and the popular arts, and these combined in the first programme in John Schlesinger's short film about Tom Arnold's Harringay circus. Schlesinger directed a number of short, strongly visual films for the strand's early seasons, including The Innocent Eye, 'a study of the child's imagination', broadcast on 9 November 1958, and Hi-FiFo-Fum, about domestic Hi-Fi fanatics, broadcast on 12 April 1959. After he joined the programme as Schlesinger's successor, Ken Russell made a number of early films for Monitor that were similarly concerned with popular pastimes and folk art, including From Spain to Streatham (1959), about the guitar craze of the moment; Variations on a Mechanical Theme (also 1959) about mechanised music; and The Light Fantastic (1960), which is a marvellously inventive study of popular dance. Russell also directed his first film about contemporary artists, Scottish Painters, broadcast on 25 October 1959. ${ }^{4}$ This 11-minute study of Robert MacBryde and Robert Colquhoun is a quiet and reflective tribute to the painters that offers little sense of their bohemian ways or their relationship as lovers. Opening with a journey into

\footnotetext{
${ }^{4}$ The film is available online from BBC Arts:

http://www.bbc.co.uk/programmes/p02j4ps1; accessed 2 February 2015.
} 
'deep' England, past a parish church and through the hanging fronds of trees, the camera arrives at a Tudor cottage in Suffolk which the two Roberts have apparently rented as a studio for just a pound a week. Russell takes their paintings seriously, accompanying shots of a range of canvases, with careful moves in and out, by voice-over comments from the artists and by a Debussy arrangement of the music of Erik Satie. Much of the film features the recorded voices of the artists, but as with other early Monitor films by Russell such as Gordon Jacob (1959) and Old Battersea House (1961) a scripted narration, spoken in this case by Scottish actor Allan McClelland, is included to anchor the images.

Scottish Painters as well as Russell's folk art films clearly respect the boundary between the high art of the former and the low of the latter, and neither mixes, mashes or muddles pop culture and tradition, history and the now as the director does for the first time in Pop Goes the Easel. Nor despite the highly stylised camerawork and mocking grotesquerie of The Light Fantastic does his work before the 1962 study of Pop bring together in any sustained way what could be understood as indexical documentary images with constructed fiction and fantasy. Yet even in the earlier films the director is exploring this boundary, as he does with the briefest of shots in Scottish Painters showing a cloaked woman walking away from the camera on a seashore. Clearly, to twenty-first century eyes at least, a 'fictional' element of reconstruction, the shot is included to conjure up the peasant people of Scotland who made such an impression on Robert Colquhoun during his childhood and who he frequently depicted in his paintings. Just over two years later when Pop Goes the Ease/ was produced, Russell was far more confident about moving between different registers of documentary 'truth'. Even so, the filmmaker had constant battles with the series editor and presenter Huw Wheldon about the legitimacy or not of including dramatised elements in documentary profiles; as Michael Brooke has written, 'Wheldon was constantly reining in Russell's ambition by reminding him that he did not work for the drama department and that many of his ideas were unaffordable.' 
After the opening sequence of Pop Goes the Easel in the fairground, the film focuses on each of the artists in turn - Peter Blake is seen dreaming of Brigitte Bardot, who by some smart intercutting of a feature film clip seems to get out of Blake's bed; Peter Phillips stars in a eccentric Godardinfluenced girl-and-a-gun drama of returning to his flat in a Chevy driven by a very cool black dude and finding two laconic women there, one of whom is playing pinball; Derek Boshier eats his cornflakes and dreams of England, as he talks about his art (by contrast, Phillips remains almost silent throughout his segment); and then the film cuts first to an exterior shot with extensive foreground brambles of what we will learn is Pauline Boty's flat and then to the artist laying out drawings on the floor of a curving corridor. Kneeling and lost in contemplation of her work, Boty is startled by a threatening female voice speaking in German. She looks up to see a regimented line of women, one of whom steps forward over her artworks. Boty slaps her face, at which point a women with dark glasses in a wheelchair comes forward and Boty turns to flee. Filmic echoes here might include films by Alfred Hitchcock and aspects of German Expressionist cinema, but then an insistent bell on the soundtrack is revealed by a shot of Boty apparently asleep to be her alarm clock and the elaborate fantasy sequence is normalised as her nightmare. The film makes a swift generic shift to that of a romantic comedy underscored by an instrumental version of George and Ira Gershwin's 'A Foggy Day', which was first featured in the 1937 English-themed Hollywood musical A Damsel in Distress.

Blake, Boshier and Phillips arrive at Pauline Boty's flat. They read magazines together and following a 60-second shot in which the camera simply observes Boty combing out her hair as she stares into a mirror Peter Blake talks with her about her collages. The extended sequence that Russell devotes to Boty's modest assemblages, accompanied by lush orchestral music, indicates how engaged he was by her method of cutting and pasting. Spliced into the discussion are Hollywood images of musicals, including the child star Shirley Temple, and the soundtrack song of 'They All Laughed' by 
George Gershwin continues across a dense progression of details from Boty's paintings before we see the artist herself, dressed in top hat and tails performing Temple's signature song 'On the Good Ship Lollipop'. Throughout this sequence with Boty there is a strong sense of selfreflexivity, for the documentary is working with her techniques to create itself as a Pop Art assemblage, which Lisa Tickner has described as 'a spliced and shuffled collage of images that startled its viewers and paid cinematic homage to the inspiration of his artistic subjects.' (2012) Pop Goes the Easel is, in a sense, pure Pop on film. In 1991, in a BBC programme dedicated to the exhibition Pop Art at the Royal Academy of Arts, Ken Russell spoke about how working with the four artists was 'a very liberating experience'. Talking of the interests and passions of the artists, he said, 'I sort of got infected with this sort of new spirit, this new revolution and I got rid of this old documentary heritage, which was very burdensome for us on the programme... I went with the imagery, I cut fast, I cut to the slot machines, I went up in space... it was crazy, it was fantastic, and this I think infiltrated into the film itself, the very fabric of the film... and made me think of shooting film and editing film and making film in an entirely new way.' (1991)

Russell may have believed that he was working 'in an entirely new way', and yet the film betrays a constellation of connections to the visual culture of the decade before Pop Goes the Easel. Feature films of the nouvelle vague are noted above as a point of comparison, but the fragmented editing style is also reminiscent of Richard Lester and Peter Sellers' comic short The Running, Jumping \& Standing Still Film (1959). Another influence may well have been the work of the artist Bruce Lacey who collaborated with Lester and Sellers on The Running, Jumping \& Standing Still Film as well as making numerous contributions, often employing Surrealist cut-up techniques, to the BBC comedy series It's A Square World (1960-1964). Russell clearly knew Lacey's work since his next film for Monitor after Pop Goes the Ease/ was a short portrait of the artist, The Preservation Man, broadcast on 20 May 1962. Pop Goes the Easel also has quieter, more reflective moments that are closer to the spirit of independent documentaries 
associated with the films of the Free Cinema movement in the mid-1950s and also those made with poetic images and non-synchronous sound by Denis Mitchell such as Special Enquiry: Teenagers (1955, BBC), Morning in the Streets and Soho Story (both 1959, BBC). Of the Free Cinema films, perhaps the one closest to Pop Goes the Easel is Karel Reisz and Tony Richardson's Momma Don't Allow (1956), filmed in the Wood Green Jazz Club. At the centre of Momma Don't Allow is a vibrant, extended sequence of dancing to the Chris Barber Jazz Band, which is paralleled in Pop Goes the Ease/ by the lengthy scene of the artists and their friends twisting at a party. There are echoes too in Russell's film of photojournalism essays by photographers like Bert Hardy, Thurston Hopkins and Grace Robertson for illustrated magazines, and most especially until its closure in 1957, Picture Post. Although these essays were often accompanied by written texts, the photographers aspired to a form of visual narrative that could be understood solely from the images. One staple form for such stories was 'a day in the life of a subject', the structure that loosely underpins Pop Goes the Easel. Russell himself published his first photo-essay about 'Teddy Girls' in Picture Post in 1955, and he continued to work as a freelance photographer until joining the BBC in early 1959. A further element of film-like collage from these years were the slide shows of images from disparate sources organised by the artist Eduardo Paolozzi and others and shown at meetings of the Independent Group between 1952 and 1955, the principle of which Paolozzi translated to film in A History of Nothing, completed in either 1961 or 1962.

Distinct from the earlier tradition of the arts on television but yet embedded in the visual culture of independent film and the art world of the time, Pop Goes the Easel also looks forward to Ken Russell's later work. Both Pauline Boty and Derek Boshier appear as actors in his later television films; Ken Higgins and Allan Tyrer were among the production personnel who worked on the director's later films for television; the artists appear to "watch" a wrestling match (although they were filmed in close-up and Canadian archive footage of a bout was intercut with these shots) that is a distant pre- 
echo of a notable scene between Alan Bates and Oliver Reed in Women in Love (1969); there is a shot of Pauline Boty staring from her window that suggests a key image of Glenda Jackson towards the close of The Music Lovers (1970); and a pinball machine was to have a central place in Tommy (1975). But the contemporary reception of the film gave little indication, at least as it has left traces in the archives, of its significance. Both critics and many viewers were bemused by its first appearance, and it scored just 47 on the BBC's Reaction Index (when the average for Monitor was 65). Writing in The Observer, however, Maurice Richardson found it 'a lively, rather appealing exercise in Pop Surrealism' (1962: 26).

Later critical engagements with the film include Kevin Flanagan's essay in his 2009 book Ken Russell: Reviewing England's Last Mannerist and Simon Faulkner's 1998 Ph.D. thesis A Cultural Economy of British Art. Faulkner critiques Russell as one of those "who could articulate a particular kind of discourse on popular culture from already established social locations of privilege and authority' (1998: 399). For him, any progressive potential of the film is controlled by its context within the high-culture frame of Monitor, which structures and contains it. Such a reading fails to recognise how the film's intense identification with its subjects, their ideas and their art is achieved throughout, and how this is especially the case in the vital, vibrant - and wordless - sequences such as those at the funfair and at the party, which is discussed below. Kevin Flanagan is far more positive about the film, writing that 'While Russell and others view his primary conceptual victory with the BBC as being over his eventual ability to use actors to portray dead artists in the context of documentary history, I view his collapsing of high/low distinctions, his broadcasting culture as a "whole way of life", and his refusal to think about art in older, Arnoldian terms as his most important legacy' (2009: 80).

In certain of Ken Russell's later films, including Mahler (1974), 'high/low distinctions' are comprehensively collapsed, but I am not certain that this is the case in Pop Goes the Easel. The film culminates in a seemingly 
unmotivated (apart from by the loose morning-to-night structure of the film) four-minute sequence of a party cut to the song 'Twist Around the Clock'. Imbued with a sensual, spirited energy, the scene is a singular trace of the London art world in early 1962, with Celia Birtwistle, David Hockney, Richard Smith (in whose studio this was filmed), Joe Tilson and Pauline Fordham identifiable among the many dancers. But the scene features little or nothing in the way of conventional information about the work or world of the four featured artists. Remarkably, however, it underscores the performative quality of the film as a whole, and especially the of the participation within it of Pauline Boty, who looks into the camera at one point as she is dancing and by winking to the viewer conjures up a moment of intimate complicity. Then the film fades to black before returning to the soundtrack of J. S. Bach's 'Concerto for Four Harpsichords in A Minor' with a shot each of first Phillips, then Blake, then Boshier and finally Boty, each of whom is quietly and studiously at work on a canvas towards which the camera zooms in slowly. The Pop of the party is contrasted with the conventional production of art. This final sequence was added at Huw Wheldon's insistence (Ferris 1990: 152), and while it grounds the film in material and process it also betrays an absurdist, parodic quality. For this is a stylised and yet at the same time highly conventional depiction of artists apparently at the moment of creation. Here, finally (for the film has constantly deferred this), is what Philip Hayward has identified in a wide range of films about visual artists as the 'extreme "fetishisation" of the actual moment of creation' (1988: 8; emphasis in the original). And this is the 'moment' that has been fundamental to depictions of visual artists as is exemplified by Hans Namuth and Paul Kalkenberg's film Jackson Pollock (1951) but which is also central to the short film portraits made by Hans Curlis from 1922 onwards under the collective title of Schaffende Hande (Creative Hands). Russell both satisfies our (and Wheldon's) desire for these shots and at the same time, and especially with his lightly parodic use of music, highlights how this is a desire that can never be satisfied. 
As viewers, we have seen the artists surrounded by and in thrall to the popular culture of the time - and indeed in the Twist sequence it is as if we ourselves have been immersed in this - but in this final sequence we are brought back to high art and to the conventional depiction of its creation. As Lisa Tickner has observed, it is as if Roland Barthes could have been writing about this moment in his 1980 essay 'That Old Thing Art...' Barthes describes Pop Art as '... the permanent theater of this tension: on one hand the mass culture of the period is present in it as revolutionary force which contests art; and on the other, art is present in it as a very old force which irresistibly returns in the economy of societies. There are two voices, as in a fugue - one says "This is not Art", the other says, at the same time" I am Art." (1980: 21) By extension, Barthes' insight can be taken to apply to the 'voices' of the other pairings identified above as structuring Pop Goes the Easel, which contains, for example, numerous still, stable artworks and yet as a whole is a fluid film. 'This is a documentary', the film demonstrates throughout, and yet over and over it says, 'I am a fiction, I am a fantasy'. The world of Pop Goes the Easel contains both the quiet, abstracted intellectualism of the commentary on their works by each artist and at the same time the unrestrained and frequently sexualised bodies of the artists in motion dancing, playing pinball and colliding in bumper cars. And then there is Wheldon's introduction explaining that the artists in the film use as their subject-matter 'the world of film-stars, the Twist, science fiction, pop singers - a world which you can dismiss if you feel so inclined, of course, as being tawdry and second-rate'. Counter-pointed to this refined put-down is the film's own excitement at and embrace of exactly this world. Each of these structuring tensions contributes to the fascination and complexity of the finished film.

Throughout Pop Goes the Easel, not only does Russell over-turn the dominance of word over image in the arts on television through to 1962, but he also skilfully weaves his filmic fugue from the various pairings of concerns, alternating and counterpointing This is not... and, at the same time, I am... Rather than collapsing the distinctions of high/low, 
documentary/fiction, singular/multivalent and mind/body, Russell keeps each pairing in play and in performance together. Which is why, in this film especially, but also in other films that he went on to create for Monitor, Russell's achievement deserves celebration. The easel - and by extension high art - is, you might say, most certainly popped in Pop Goes the Easel, just as it is in much of Russell's best work, but at the same time it is also propped, and so sustained and reinforced for the audience.

\section{References}

Barthes, Roland (1977), 'Rhetoric of the Image', translated by Stephen Heath, in Barthes, Roland, Image-Music-Text, Glasgow: William Collins, pp. 32-51.

Barthes, Roland (1980), 'That Old Thing Art . . .' reprinted in Paul Taylor ed., Post-Pop Art, Cambridge, Mass.: MIT Press, 1989, pp. 21-31.

Brooke, Michael (n.d.), 'Ken Russell: The Monitor Years', BFI ScreenOnline, http://www.screenonline.org.uk/tv/id/1030022/ (accessed 12 May 2015)

Faulkner, Simon (1998), A Cultural Economy of British Art: 1958-1966, Ph.D. thesis, Manchester University, 1998.

Ferris, Paul (1990), Sir Huge: The Life of Huw Wheldon, London: Michael Joseph Ltd.

Flanagan, Kevin (2009), 'Television, Contested Culture, and Social Control: Cultural Studies and Pop Goes the Easel', in Flanagan ed., Ken Russell: Reviewing England's Last Mannerist, Plymouth: Scarecrow Press, 2009, pp. 65-84.

Hayward, Philip (1988), 'Introduction: Echoes and Reflections: The Representation of Representations', in Philip Hayward ed., Picture This: Media Representations of Visual Art \& Artists, London: John Libbey \& Company, pp. 1-26.

The Listener (1939), 'Traditional Versus Modern Art: A Televised

Discussion', XXI: 543, 8 June 1939, pp. 1191-95, 1223.

'P. L.' [Peter Lennon] (1983), 'Portrait Maker', The Listener, 13 January 1983 , p. 27. 
Radio Times (1936), 'The Autumn Galleries', 30 October 1936, p. 89.

Radio Times (1938), 'Artists and their Work: Surrealism - Objects and Pictures', 14 January 1938, p. 17.

Radio Times (1939), 'Television Surveys No 9: Non-Members Varnishing Day at the Royal Academy', 21 April 1939, p. 16.

Radio Times (1947), 'The Eye of the Artist', 3 October 1947, p. 35.

Radio Times (1948), 'The Eye of the Artist: Life Class', 14 May 1948, p. 26.

Redington, Michael (1993), unpublished transcript of interview conducted by John Wyver for the television programme K: Kenneth Clark 1903-1983, broadcast 10 October 1993, BBC2; author's papers.

Reith, J. C. W. (1924), Broadcast Over Britain, London: Hodder and Stoughton.

Richardson, Maurice (1962), 'The Progress of Addiction', The Observer, 1 April 1962, p. 26.

Russell, Ken, interview in The Pop Show, broadcast 14 September 1991, BBC2.

Stephens, Chris and Stonard, John-Paul eds. (2014), Kenneth Clark: Looking for Civilisation, London: Tate.

Tate, Sue (2003), Pauline Boty: Pop Artist and Woman, Wolverhampton: Wolverhampton Art Gallery, 2013.

Tickner, Lisa (2012), 'Pop Goes the Easel', unpublished manuscript in author's papers.

Wyver, John (2007), Vision On: Film, Television and the Arts in Britain, London: Wallflower Press.

Wyver, John (2014), 'Television' in Stephens, Chris and Stonard, John-Paul (2014), pp. 123-131. 